\title{
FATHOM
}

\section{The Narrative Silence in The Mayor of Casterbridge}

Le silence narratif dans The Mayor of Casterbridge

\section{Tomomi Nagatomi}

\section{OpenEdition}

\section{Journals}

Electronic version

URL: http://journals.openedition.org/fathom/463

DOI: $10.4000 /$ fathom.463

ISSN: 2270-6798

\section{Publisher}

Association française sur les études sur Thomas Hardy

\section{Electronic reference}

Tomomi Nagatomi, « The Narrative Silence in The Mayor of Casterbridge », FATHOM [Online], 2 | 2013 Online since 21 September 2013, connection on 19 April 2019. URL : http://journals.openedition.org/ fathom/463 ; DOl : 10.4000/fathom.463

This text was automatically generated on 19 April 2019 


\title{
The Narrative Silence in The Mayor of Casterbridge
}

\author{
Le silence narratif dans The Mayor of Casterbridge
}

Tomomi Nagatomi

1 One of the most conspicuous narrative blanks or "silences" in the corpus of Thomas Hardy's works is a span of 18 years that follows the notoriously dramatic episode of Michael Henchard's wife-sale in a drunken stupor at the Weydon-Priors fair in The Mayor of Casterbridge. So blatantly noticeable, this blank almost obscures other blanks in the narrative of the novel. A striking example can be seen in Elaine Showalter's casual comment on Elizabeth-Jane's puzzling silence. When dark rumours are rife in Casterbridge about Henchard's hidden past including the shocking fact that he sold his wife and daughter to a sailor, and yet Elizabeth-Jane does not "confront [Henchard] with it", Showalter lightly observes that "Hardy seems to have forgotten to show her reaction" (Showalter 401). Showalter's dismissal of Elizabeth-Jane's silence as negligence on the author's part is an extreme example of what has been a commonplace in the criticism of the characterisation of the novel: Elizabeth-Jane, Farfrae and Lucetta have all been considered as rather flat. Of Elizabeth-Jane and Henchard, for example, one critic remarks that although they "are presented as emotionally 'deep' [...] there is little of the somatic depth and penetrability so characteristic of Hardy", while Farfrae is constructed in opposition to Henchard, as "shallow where Henchard is deep" (Garson 96-97). Another critic also applies the word "shallow" to Farfrae, equating him to Newson who is only weakly attached to his daughter Elizabeth-Jane (Raine 160). Each critic employs a dichotomy of deep/shallow in different contexts, and yet we do perceive, among the characters in this text, glaring differences in intensity and density, which are not entirely unrelated to the peculiar texture of this novel. Major characters though they are, Elizabeth-Jane, Farfrae and Lucetta are indeed not delineated as clearly as their prominent roles suggest they should be. This narrative blank of the trio is, I would like to contend, not due to the author's careless mistake, but actually a narrative silence inextricably intertwined with the textual structure. 
2 If Elizabeth-Jane and Farfrae seem to be "shallow", it may be because the narrator remains strangely reserved about them. It is accordingly often hard to speculate upon the range of their knowledge. Arguably, it is the narrator's deliberate intention to avoid probing deeply into their feelings when they actually perceive more than they seem to. Useful to demonstrate this assumption is the passage right after the scene in which Elizabeth-Jane and Lucetta are nearly attacked by a savage bull. Upon Lucetta's departure under Henchard's escort Farfrae comes along; listening to what has happened, he does not dare to catch up with Henchard and Lucetta.

"She has gone on with Mr. Henchard, you say?" he inquired at last.

"Yes. He is taking her home. They are almost there by this time."

"And you are sure she can get home?"

Elizabeth-Jane was quite sure.

"Your step-father saved her!"

"Entirely!"

Farfrae checked his horse's pace; she guessed why. He was thinking that it would be best not intrude to on the other two just now. Henchard had saved Lucetta, and to provoke a possible exhibition of her deeper affection for himself was as ungenerous as it was unwise.

[...] The face of the woman was frequently turned back, but Farfrae did not whip on the horse. (Hardy 192-193; emphases added)

3 Here the narrator does not look into Farfrae's mind in order to figure out the reason why he doesn't follow them. Instead, the narrator makes Elizabeth-Jane guess. The italicized sentences are her inner monologue, and her supposition seems reasonable enough, admittedly, to explain away Farfrae's attitude. Both Henchard and Elizabeth-Jane are still ignorant of the fact, but Farfrae has just got married to Lucetta in another town. Taking this fact into consideration, Farfrae must have been torn with more conflicting emotions than Elizabeth-Jane could conjecture. But as long as the narrator eschews an inquiry into Farfrae's mind, there is no way of our grasping what exactly he is thinking.

4 A similar detachment of the narrator extends to Elizabeth-Jane who, unlike a conventional heroine, hardly expresses her opinions and feelings, preventing readers from fathoming the extent of her awareness of her complicatedly displaced origin. The text nevertheless exhibits an interesting rhetoric which renders her purported ignorance of the truth about her parentage questionable. On making his confession of his fatherhood to Elizabeth-Jane, Henchard disloyally ignores his deceased wife's request and reads her letter to learn that Elizabeth-Jane is not his daughter, whom he had abandoned nearly twenty years before, but the daughter Susan subsequently had by Newson. As a result, when the narrator speaks from Henchard's point of view, it is natural that he should call Elizabeth-Jane his "step-daughter". When it comes to Elizabeth-Jane's internal focalisation, however, it is quite another matter.

[Lucetta] did not tell Elizabeth that the person expected was the girl's stepfather.

They sat in adjoining windows of the same room in Lucetta's great stone mansion, netting, and looking out upon the market, which formed an animated scene. Elizabeth could see the crown of her stepfather's hat among the rest beneath, and was not aware that Lucetta watched the same object with yet intenser interest. (Hardy 142)

5 Henchard is appropriately referred to as "the girl's stepfather" from the viewpoint of Lucetta, because at this point people in Casterbridge are uninformed about Henchard's detestable act of wife-selling; they simply believe that Henchard and Susan are distantly related and Elizabeth-Jane is a daughter by Susan's previous marriage. Yet a few 
sentences down in this passage the word "stepfather" appears again, and this time it is not clear whether the focalizer is Elizabeth-Jane or the narrator.

6 As an illustration of the narrator's perplexing handling of the word "stepfather", I would like to give another and more obvious example; in the following scene Elizabeth-Jane and Lucetta are walking in the crowd when they go past Henchard.

Then something seemed to occur which his stepdaughter fancied must really be a hallucination of hers. A murmur apparently came from Henchard's lips in which she detected the words, "You refused to see me!" reproachfully addressed to Lucetta. She could not believe that they had been uttered by her stepfather; unless, indeed, they might have been spoken to one of the yellow-gaitered farmers near them. (Hardy 157)

7 Despite his function as a mouthpiece for Elizabeth-Jane, the narrator still uses the word "stepfather". The term may not arouse suspicion in the readers since they are already informed that Elizabeth-Jane is not Henchard's daughter, while they also know that at this stage Elizabeth-Jane still believes Henchard to be her real father. Yet confronting the word "stepfather", some readers may feel odd, and harbour disturbing doubts about the narrator's intention of choosing this particular word. Of course this word choice does not provide decisive proof that Elizabeth-Jane actually suspects that Henchard is not her biological father, but it may well be said that the narrator tantalisingly preserves the possibility by employing the tricky rhetoric of father/step-father.

This rhetorical ambiguity should be ascribed to the jarring issue that lies at the core of the text, that is, the indecent nature of the secret surrounding Elizabeth-Jane's parentage. Somehow a considerable amount of criticism on The Mayor of Casterbridge has avoided this critical matter. It is true that the text seems blithely indifferent to Elizabeth-Jane's illegal origin, showing so little hesitancy in allowing her to marry Farfrae. One may pay little heed to her illegitimacy, regarding it as the kind of sensationalism frequently found in Hardy's novels. But her marriage to Farfrae provides, it should be noted, the very moment when she can extricate herself from the accursed brand of illegitimacy, the state of being socially non-existent. To overlook her illegitimacy would therefore lead to a total misreading of the narrative silence about Elizabeth-Jane, and also of the subversive nature of this text.

9 The text's precautionary measures to safeguard Elizabeth-Jane against social condemnation inevitably relegate her to the background, to the position of, as many critics point out, an observer. Significantly, her position as an observer and her grave seriousness combine to constitute a frame of reference with which readers comprehend the text. Her seriousness, or "her almost paranoid sobriety" (Garson 112), ironically serves, in this theatrical text, to lend credence to her moral judgement. Still more ironically, her strong inclination towards respectability seems to attest to her natural integrity; given social prestige by her mother's marriage to Henchard, Elizabeth-Jane is not enraptured by good fortune, nor does she care about a style of dress befitting the status of a mayor's daughter. Instead, she tries to cultivate her mind by acquiring knowledge from reading. It is indeed ironical, I should say, because try as she might, Elizabeth-Jane, being illegitimate and thus placed beyond the bounds of society, can never attain respectability. The text's strong emphasis on respectability as a typical characteristic of Elizabeth-Jane is nothing but the obverse of the extraordinary negativity of illegitimacy. 
10 Alongside its frequent reference to "respectability" as a potentially viable attribute for Elizabeth-Jane, the text contrives a structural device to nullify the effect of her illegitimacy. Thus, Lucetta is brought in the text as an indispensable constituent of that device and connected to Elizabeth-Jane in a flagrantly abrupt and forceful way: "The personage was in mourning like herself, was about her age and size, and might have been her wraith or double, but for the fact that it was a lady much more beautifully dressed than [Elizabeth-Jane] " (Hardy 125; emphases added). Introduced as the double of ElizabethJane for no reason at all, Lucetta immediately takes the place of Elizabeth-Jane and becomes the centre of public attention. Even Farfrae loses all interest in Elizabeth-Jane, turning his admiring gaze exclusively on Lucetta. Totally eclipsed by Lucetta, ElizabethJane seems superseded by her. The indisputable fact is, however, that there is something awkward, something artificial about Lucetta. Her artificiality is mainly due to the exaggerated emphasis on her colourful dresses. It is her colourful attire, the text almost asserts, that enables Lucetta to win Farfrae away from Elizabeth-Jane. Put another way, we might say that Lucetta is required only to serve as a sign, not as a whole person of depth and character. Surreptitiously marrying Farfrae, Lucetta is, much to the annoyance of the workers and peasants in Casterbridge, "gaily dressed" in public as a mayor's wife, at which Nance Mockridge hurls a curse: "I do like to see the trimming pulled off such Christmas candles. I am quite unequal to the part of villain myself, or I'd gie all my small silver to see that lady toppered" (Hardy 248-249). Nance's remark triggers the dreadful catastrophe of the skimmity-ride. In this old custom, an effigy of Lucetta is "dressed just as she was dressed" (Hardy 258) - wearing a dark red silk dress, white stockings, and coloured shoes, having a green parasol in her hand. Clothing is, no doubt, absolutely fatal to Lucetta.

11 Her style of dressing seems to form the core of the discourse on Lucetta, a woman with a past, who seems to have been sexually involved with Henchard in former times. As well as dress, some other expressions peculiar to her, such as "coquette" (Hardy 152) and "giddy girl" (Hardy 75), also foster the dubious nature of the discourse on her. The most crucial word in this context is, it should be noted, a "garrison town" (Hardy 141). Lucetta tells Elizabeth-Jane that she once lived in garrison towns. Among various elements closely associated with the word "garrison towns" in late nineteenth-century Britain, prostitute and prostitution are included without any doubt:

In July 1864, Parliament passed the first Contagious Diseases Act, to continue in force three years. The act applied to eleven garrison and dock towns in England and Ireland; although not legalizing prostitution, it provided that a woman identified as a diseased prostitute by a plainclothes member of the metropolitan police undergo examination. If found diseased, she could be detained in a hospital for up to three months. (Walkowitz 1-2)

Under the Contagious Diseases Act, however, quite a few women were mistakenly arrested because the police judged whether they were prostitutes or not only from the way they were dressed. The way of dressing and the identity of a prostitute are an inseparable pair.

The most visible symbol of the prostitute's relative affluence was her dress. Middleclass commentators repeatedly complained that the "painted dressy women flaunting along the streets" in "dirty white muslin and greasy cheap blue silk" exercised a pernicious influence on the impressionable servant girls in the neighbourhood. The dress code of prostitutes also served as a way of advertising themselves and attracting male customers. (Walkowitz 26) 
13 To exemplify how the discourse of gaily dressing and that of the gay lives of prostitutes intermingle with each other in the Victorian socio-cultural context, I would like to refer to an article entitled "Saving the Innocence", which appeared in The Fortnightly Review in 1885. The article insists on the necessity to try to reduce the number of prostitutes, maintaining that the major reasons for girls' ruin are their "bad companions, love of dress, and drink" (Jeune 346-347). The aim of my argument lies not in identifying Lucetta as a prostitute, but in verifying that the descriptions of Lucetta resonate with a discourse suggestive of prostitution, revolving around the phrase "gaily dressed" that functions as a lurid signal of the Victorian prostitute. Laying almost disproportionate emphasis on Lucetta's bright dress, thereby implicating her in a discourse of prostitution, the text succeeds, I would like to argue, in the valorisation of Elizabeth-Jane, making her illegitimacy less obvious.

14 This valorisation is possible because illegitimacy has a negative connotation similar to that of prostitution. Confirming this fundamental fact, we may understand the text's motive for introducing a bizarre episode which flatly contradicts Elizabeth-Jane's sober indifference to dressing up and reveals her hidden desire. It is a pair of gloves which sparks off her insatiable lust for the whole outfit. Midway through the passages in question, the narrator informs us that "Henchard gave Elizabeth-Jane a box of delicately tinted gloves one spring day", and then goes on:

She wanted to wear them, to show her appreciation of his kindness, but she had no bonnet that would harmonize. As an artistic indulgence she thought she would have such a bonnet. When she had a bonnet that would go with the gloves she had no dress that would go with the bonnet. It was now absolutely necessary to finish; she ordered the requisite article; and found that she had no sunshade to go with the dress. In for a penny for a pound; she bought the sunshade; and the whole structure was at last complete. (Hardy 90)

15 For the second time we perceive an almost "paranoid" aspect to Elizabeth-Jane's character. Quite unexpectedly but plainly this paragraph shows that Elizabeth-Jane is not actually indifferent to her appearance, but rather meticulously fastidious in her choice of attire. Revealing Elizabeth-Jane's passion for an outfit, the text paves the way for an exchange of Lucetta for Elizabeth-Jane. Yet the process of the displacement is only halfway towards completion; it requires one perilous step further, for the value of Elizabeth-Jane should be the same and as negative as that of Lucetta:

At first Miss Newson's budding beauty was not regarded with much interest by anybody in Casterbridge. Donald Farfrae's gaze, it is true, was now attracted by the mayor's so-called step-daughter, but he was only one. The truth is that she was but a poor illustrative instance of the prophet Baruch's sly definition: "The virgin that loveth to go gay."

When she walked abroad she seemed to be occupied with an inner chamber of ideas, and to have slight need for visible objects. She formed curious resolves on checking gay fancies in the matter of clothes, because it was inconsistent with her past life to blossom gaudily the moment she had become possessed of money. But nothing is more insidious than the evolution of wishes from mere fancies, and of wants from mere wishes (Hardy 90; emphases added).

Placed immediately prior to the passage describing the outpouring of Elizabeth-Jane's repressed desire, this narrative sequence is significantly studded with the words "gay" and the like. The implication is obvious: there is a very strong possibility that ElizabethJane will "go gay". The text divulges a sense that despite surface differences between them, Elizabeth-Jane and Lucetta share a dangerous propensity for dressing gaily. Forced 
into the text as the double of Elizabeth-Jane, Lucetta is thus able to fill the role of a substitute for her, taking upon herself all the negativity; she is dressed gaily, insistently connected with the discourse of prostitution, only to fall a victim to the skimmity-ride and die.

17 Additionally, with the novel the discourse of prostitution works steadily not only in relation to individuals but also in connection with places: it effectively permeates and undermines the town of Casterbridge. The most pernicious sources from and in which the discourse spreads are Mixen Lane and High-Place Hall. Geographically marginalised, Mixen Lane locally symbolises the seamy side of the town, looming up ominously in the novel. In that area where "[v]ice ran freely in and out certain of the doors of the neighbourhood" (Hardy 236), the women who put on "white aprons over dingy gowns" were habitually seen. The narrator knowingly tells us: "A white apron is a suspicious vesture in situations where spotlessness is difficult: moreover the industry and cleanliness which the white apron expressed were belied by the postures and gaits of the women who wore it" (Hardy 237). The passage tells us that a white apron paradoxically signifies a prostitute in Mixen Lane; everything here seems to connote prostitution. On the other hand, High-Place Hall, a mansion where Lucetta lives, is, by contrast to Mixen Lane, located near the centre of the town, and yet possesses a treacherous aspect as well. It has a façade which overlooks the bustle of the lively market place, whereas the eerie back door of the mansion bears the lingering trace of its "past history - intrigue": where people came "from all sorts of quarters in the town" and "nameless infants [...] used to disappear" (Hardy 131-132). Erasing the boundary between the inner surface and the outer, just like a Möbius strip, the discourse of prostitution infuses Casterbridge, and thereby becomes an effective veil over the sign of Elizabeth-Jane's illegitimacy.

As if taking after Lucetta, Elizabeth-Jane eventually marries Farfrae to become a mayor's wife. Although she seems to be following in Lucetta's footsteps, Elizabeth-Jane does not repeat her tragic death. While directing their angry fire at Lucetta, the workers and peasants in Casterbridge accept Elizabeth-Jane instead. Stirred up at first by the news of the marriage between Farfrae and Elizabeth-Jane, they soon get lost in their own busy lives, and do not care about Elizabeth-Jane's household any more. This is the outcome of the author's contrivance to make Elizabeth-Jane survive in the community of Casterbridge. The contrivance is quite meticulous, I should say, in that the relationship between Elizabeth-Jane and Lucetta involves the process of both identification and differentiation. As we have already seen, Elizabeth-Jane requires her double who has a sign as negative as illegitimacy, identifying herself with Lucetta through her hidden propensity to "go gay". At a certain point, however, she has to differentiate herself from Lucetta in order to remain alive. It is true that the text constantly underlines her indifference to dressing up and her omnivorous reading as outward manifestations of her strong yearning for respectability, trying to impress on the reader's mind a distinct contrast between Elizabeth-Jane and Lucetta. But there is a momentous scene in which we can witness first-hand the instant Elizabeth-Jane separates herself from Lucetta. Lucetta then tells Elizabeth-Jane about her past:

"As a girl I lived about in garrison towns and elsewhere with my father, till I was quite flighty and unsettled. He was an officer in the army. I should not have mentioned this had I not thought it best you should know the truth."

"Yes, yes." She looked thoughtfully round the room - at the little square piano with brass inlaying, at the window-curtains, at the lamp, at the fair and dark kings and queens on the card-table, and finally at the inverted face of Lucetta 
Templeman, whose large lustrous eyes had such an odd effect upside down. (Hardy

141)

19 it is easily imagined that Elizabeth-Jane will not disclose her illegitimacy. Those who
know the secret all disappear from the text: both Susan and Henchard pass away and it is
suggested that Newson is to leave Casterbridge soon. It is only Elizabeth-Jane and Farfrae that are left to know the secret. We can assume that they are most likely to take the secret to the grave. The narrator's reluctance to enter into their feelings could be, one may argue, caused by this secret that Elizabeth-Jane and Farfrae share. The narrative silence which presents their minds as blanks is closely interlocked with Elizabeth-Jane's illegitimate origin.

21 Having concluded thus, I would like to venture a supplementary remark about Hardy's sleight of hand with which he hides in the text a cue to destabilise the upgraded status of Elizabeth-Jane. Actually there exists another secret which she keeps only to herself. The narrator innocuously lets slip the fact that "her blood was a sailor's" (Hardy 284). Indeed, Newson, her biological father, is a sailor. However, the question is what kind of person Newson is. After demoted Henchard leaves Casterbridge, Newson reveals to ElizabethJane that once he came to Casterbridge to search for her and was utterly deceived by Henchard into believing that she was already dead. Telling her so, he laughs it away as "a good joke" (Hardy 293). "A joke" or "a practical joke" in fact takes on no small importance throughout the text. According to the narrator, Newson "like a good many rovers and sojourners among strange men and strange moralities, failed to perceive the enormity of Henchard's crime, notwithstanding that he himself had been the chief sufferer therefrom" (Hardy 293). Although she seems astounded by the fact that her father is unable to distinguish right from wrong, as long as she herself bestrides the boundary between legitimacy and illegitimacy, sober and gay, Elizabeth-Jane definitely partakes of her father's immoral propensities. The Mayor of Casterbridge is most challengingly subversive of traditional values in that Hardy manoeuvred an illegitimate girl into the centre of the community. Yet the utmost subversiveness is not fully perceived unless we elucidate the structural meaning of the novel's narrative silence and what is more, the text's irresistible impulse to refer to the immoral blood that runs in Elizabeth-Jane's veins. 


\section{BIBLIOGRAPHY}

Garson, Marjorie, Hardy's Fables of Integrity: Woman, Body, Text, Oxford: Clarendon, 1991.

Hardy, Thomas, The Mayor of Casterbridge, Oxford: OUP, 2004.

Jeune, Mary, “Saving the Innocents", Fortnightly Review 44 os (September 1885): 345-356.

Raine, Craig, "Conscious Artistry in The Mayor of Casterbridge", in New Perspectives on Thomas Hardy, ed. Charles P. C. Pettit, London: Macmillan, 1994, 156-171.

Showalter, Elaine, "The Unmanning of the Mayor of Casterbridge", in The Mayor of Casterbridge, ed. Phillip Mallett, New York: Norton (Norton Critical Edition), 2001, 391-405.

Walkowitz, Judith, Prostitution and Victorian Society: Women, Class, and the State, Cambridge: Cambridge UP, 1995.

\section{ABSTRACTS}

One of the most conspicuous narrative blanks or "silences" in the corpus of Thomas Hardy's works is found in The Mayor of Casterbridge: a span of 18 years, following the notoriously dramatic episode of Michael Henchard's wife-sale. Interestingly, this remarkable silence makes some other problematics of narrative silence unnoticeable. Particular attention should be paid to the silence concerning Elizabeth-Jane, Farfrae and Lucetta. Indeed, they are crucially important in that Elizabeth-Jane and Farfrae finally take the place of Henchard as central figures, and that Lucetta is forcibly introduced into the text as Elizabeth-Jane's theatrical double. However, the narrator seems, rather strangely, to be only interested in their external behaviour and reserved about their inner motives and feelings.

My purpose in this paper is to elucidate the ulterior meaning of this narrative silence by focusing on Elizabeth-Jane's illegitimacy. With all due allowance for Hardy's strong inclination to deviate from the accepted mores of Victorian society, to bring an illegitimate, socially non-existent child, to the very centre of the community would be beyond the pale in the period in which he was writing. It can be proved that the narrative blank, being inextricably intertwined with the text's subversive desire of decentralisation, operates wily to cover (in both senses of the word) Elizabeth-Jane's complicatedly displaced illegal origin.

L'un des silences les plus notables de l'œuvre de Hardy apparait dans The Mayor of Casterbridge, dans ces dix-huit années qui suivent l'épisode dramatique où Michael Henchard vend sa femme à un inconnu. Ce silence est d'autant plus remarquable qu'il vient en vérité occulter d'autres problématiques narratives. Il est ainsi important de s'arrêter sur les silences qui concernent plus spécifiquement Elizabeth-Jane, Farfrae et Lucetta. Leur valeur est cruciale dans la mesure où Elizabeth-Jane et Farfrae finissent par prendre la place centrale qu'occupait Henchard dans le récit, et où Lucetta surgit dans le texte comme le double théâtral d'Elizabeth-Jane. Curieusement, il semble pourtant que le narrateur ne s'intéresse qu'à leur comportement extérieur, ne dévoilant qu'à peine leurs sentiments ou motivations personnels.

Cet article cherche à comprendre le sens de ces silence narratifs en s'arrêtant sur la question de l'illégitimité d'Elizabeth-Jane. Si l'on sait combien Hardy tend à se départir du décorum de la société victorienne dans ses œuvres, la présence au centre même de la communauté d'une enfant 
illégitime, privée d'existence sociale, semble inacceptable pour la période où écrivait l'auteur. On montrera que le blanc narratif, en ce qu'il est intimement lié à l'élan subversif de décentralisation du texte, opère de manière subtile afin de couvrir et recouvrir la question de l'illégitimité d'Elizabeth-Jane.

INDEX

Mots-clés: roman, silence, narration, illégitimité, secret, double, prostitution, subversion oeuvrecitee Mayor of Casterbridge (The)

Keywords: novel, silence, narration, illegitimacy, secret, double, prostitution, subversion

AUTHOR

TOMOMI NAGATOMI

Sophia University, Tokyo 